\title{
Effects of Cashew Seeds Storage Duration on Germination and Performance of Seedlings in Tanzania
}

\author{
Abdallah R. Makale, Wilson A. Nene, Fortunus A. Kapinga, Kasinga N. Ndibanya \\ Tanzania Agriculture Research Institute-Naliendele, Cashew Research Program, Mtwara, Tanzania \\ Email: abdallah.makale@tari.go.tz
}

How to cite this paper: Makale, A.R., Nene, W.A., Kapinga, F.A. and Ndibanya, K.N. (2020) Effects of Cashew Seeds Storage Duration on Germination and Performance of Seedlings in Tanzania. American Journal of Plant Sciences, 11, 1784-1796. https://doi.org/10.4236/ajps.2020.1111128

Received: October 9, 2020

Accepted: November 27, 2020

Published: November 30, 2020

Copyright $\odot 2020$ by author(s) and Scientific Research Publishing Inc. This work is licensed under the Creative Commons Attribution International License (CC BY 4.0).

http://creativecommons.org/licenses/by/4.0/

\begin{abstract}
A field trial was set in 2018/2019 season to investigate the capacity of cashew seeds to germinate and its vegetative performance with respect to the storage period at Agricultural Research Institute-(TARI-Naliendele), Mtwara-Tanzania. The variable investigated was the duration of the cashew seeds storage period. Cashew seeds were harvested at polyclonal seed gardens (PSG) for three harvesting seasons 2016, 2017 and 2018 consecutively; seeds were sorted, weighed and soaked before sowing to test viability in respective to storage time. Using a randomized complete block design obeying factorial approach the experiment was laid with three replications. The observed growth parameters were height $(\mathrm{cm})$, number of leaves, leaf length $(\mathrm{cm})$, leaf width $(\mathrm{cm})$, leaf area (sq $\mathrm{cm})$, leaf area index (LAI), canopy diameter $(\mathrm{cm})$ and seedlings canopy ground area (sq $\mathrm{cm}$ ). The analysis was done by using GenStat under Duncan Multiple Range Test (DMRT) on seed germination. The findings indicated that cashew seeds harvested in 2018 were the superior in both germination and growth vigor differing significantly $(\mathrm{p}<0.05)$ from other seeds harvested in the previous years. Cashew seeds harvested in 2017 were weak and those harvested in 2016 were the worse such that no seeds were able even to germinate. Thus, it is recommendable to sow cashew seeds harvested at the current season for sowing than those stored for more than a year.
\end{abstract}

\section{Keywords}

Cashew, Storage Period, Seeds Germination, Growth Vigor

\section{Introduction}

Cashew (Anacardium occidentale L.) is one of the important commercial tree 
crops in the world [1] [2] [3]. These include being a source of food and income [4], prevent soil erosion [1] [5], its parts such as leaves, bark or roots are used as medicinal and nutrients [6] [7]. Cashew apple can be eaten as a fruit [1] or processed to produce various products such as syrups, juice, wine alcohol, jam, vinegar and candy [1] [5]. Cashew helps in environmental conservation as it reduces carbon dioxide emission [8] [9] [10] [11]. Cashew kernel and apples contain nutritive properties such as vitamins, sugar and minerals like calcium, magnesium, phosphorus, sodium, potassium, copper and zinc [12] [13] [14] [15] [16]. Consumption of cashew nuts reduces cases of obesity and or increased body weight [16].

Cashew crop has been an important foreign exchange earner for Tanzanian and ranked the first since 2016 to date. For instance, in 2017/2018 season, the government of Tanzania earned about 585.1 million USD from exporting cashew nuts following the country engagement in the agriculture business [17]. The crop continues to be the major source of income for more than 500,000 households in south-eastern Tanzania [18].

Traditionally, cashew in Tanzania has been grown in 5 regions which are Mtwara, Lindi, Ruvuma, Pwani and Tanga. However, in recent years cashew production has been extended to more than 17 regions including Dodoma, Tabora, Singida, Katavi, Shinyanga, Iringa, Kilimanjaro, Mbeya, Njombe, Songwe, Iringa, Kigoma and Morogoro, a situation which triggered higher demand for cashew seeds. Similarly, the government has been considered cashew as one of the national strategic crops which can improve the livelihood of the Tanzanian community and contributes to poverty reduction. Therefore, research efforts have been in the increase to ensure that more production of seeds with high quality is available and distributed to farmers. In this aspect, for the successful production of cashew in these new areas, it is essential to be assured of planting materials particularly the seeds of high quality. Strategically, high-quality seeds can be assessed by germination capacities [19] [20] [21] which include storage duration and soaking [22] or floating (Conacher et al., 1994) of seeds before sowing.

Germination is defined as a process where a seed releases a radicle for plant formation and development [23] whereas germination capacity can be referred to as the seed viability to produce firm and healthy radicle in time [24]. Several factors are associated with seed germination capacity, however, several studies indicate that seed germination is significantly affected by storage duration [25] [26]. For instance, a study by [21] recorded higher germination capacity in seeds stored for six (6) months than seeds stored for twenty-four (24) months. A study by [27] observed higher germination and sprouting on seeds stored for a reduced period compared to a longer storage period. Similar results were obtained by [2] who stated that the highest seedlings emergence of $80 \%$ to $80 \%$ were observed at early storage (30 - 90 days) and which thereafter declined to $72 \%$ at the end of 210 days, with $10 \%$ reduction. However, the study by [28] revealed no 
association between storage duration and seed germination capacity as observed that the cashew seeds emerged both at 20 and 21 days. Seed germination capacity and performance of seedling are also associated with the soaking method [22] [29]. Studies indicate that sinker seeds germinate fast and their seedlings become more vigorous than floater seeds [30] [31] and [32].

In Tanzania, Naliendele which is one of 17 agricultural research centers under Tanzania Agricultural Research Institute (TARI) is the only centre with the mandate to produce cashew seeds. The centre has been producing and distributing cashew seeds to farmers inside and outside the country. The centre distributes seeds of the current season and demands vary between years. In some cases, seeds of the previous season can remain when the demands are low. However, the centre does not distribute seed of the previous years following high demands with the supposition that their germination could be poor. Thus, the aim of this study was to find out the effect of storage duration of cashew seeds on germination and the performance of cashew seedlings. Information obtained could be used as a guide for improving recommendations regarding the use of quality cashew seeds for production in Tanzania as per [33].

\section{Materials and Methods}

We conducted an experiment from January through March 2019 to assess the effect of storage duration in the germination and performance of cashew seedlings. Selection criterion for the period was rain season as in the experimental area January to March is the rain season peak. Experiments were conducted at TARI Naliendele which is located at Latitude $10^{\circ} 35^{\prime} 60.35^{\prime \prime S}$ and Longitude $40^{\circ} 16^{\prime} 67.37^{\prime \prime} \mathrm{E}$ in Mtwara region. Mtwara region is located in the southeastern part of Tanzania. The region is characterized by a unimodal type of rainfall starting from November/December to April/May. The annual average minimum temperatures are $23.8^{\circ} \mathrm{C}-24.5^{\circ} \mathrm{C}$ and maximum temperatures are $30.7^{\circ} \mathrm{C}-$ $31.9^{\circ} \mathrm{C}$ whereas rainfall ranges between 1052.9 - $1159.6 \mathrm{~mm}$.

To examine the effect of storage duration in the germination and performance of cashew seedlings; three categories of cashew seeds were prepared; first category was for seeds harvested in 2016, second for seeds harvested in 2017 and third category considered cashew seeds harvested in 2018. All cashew seeds were sun-dried under temperatures ranging between 28 and 30 degrees centigrade for four days just after harvested in each respective year to a moisture content of $<9$. Three seedbeds each of 10 square meters were prepared for seeds sowing with respective to harvesting years $(2016,2017$ and 2018). Three lines were prepared in each seedbed and small holes of $5 \mathrm{~cm}$ deep were dag for seeds sowing. A total of 300 holes per seedbed were prepared for seed sowing. Cashew seeds were selected and sorted to remove any unwanted materials. Seed were also weighed and floated [34] for viability testing [22] [29].

The trial was set in a randomized complete block design with three replicates. Data were recorded in weekly bases for four weeks started one week after seed 
sowing. The following data were recorded; germination percent which involved the number of seeds germinated out of all seeds sown, seedling height, number of leaves, leaf length leaf width, canopy diameter, seedlings canopy ground area, leaf area and leaf area index ( $L A I)$ using indirect method as per [35] were recorded, whereas:

$$
L A I=L A / G A
$$

- Leaf Area $(L A)=$ Average Number of leaves/plant $(n) \times$ Average length $(L) \times$ width $(W)$ of leaf by an area constant k. $(L A=L \times W \times k \times n)$

- Ground Area $(G A)=$ Spacing $\times$ number of plants $\mathrm{x}$ number of rows.

All data were analyzed by using GenStat software statistical package $15^{\text {th }}$ edition, Duncan Multiple Range Test (DMRT) was used to separate the mean between treatments.

\section{Results}

Results on germination percent are shown in Table 1 below. There was highly significant difference $(\mathrm{p}<0.05)$ in seeds germination percent between years. Cashew seeds harvested in 2018 recorded higher germination percent compared to seeds harvested in 2017. However no germination recorded for all cashew seeds harvested in 2016.

Germination started in the second week after seeds being sown. Germination increased to 99.6 percent in the 4th week after sowing particularly for seeds of 2018. Seeds harvested in 2017 had a 52.4 percent germination in the 4th week compared to $2.7 \%$ which was recorded in the year 2017. Cashew seedlings varied significantly $(\mathrm{p}<0.05)$ in canopy diameter, leaf area, leaf length, width and plant ground area.

However, there was no significant differences $(p>0.05)$ between the three categories of seeds in terms of leaf area index (Table 2). Cashew seedlings for seeds harvested in 2018 significantly $(\mathrm{p}<0.05)$ grew faster than those for 2017 particularly at $4^{\text {th }}$ week and $8^{\text {th }}$ week (Table 3 ). Likewise, there were significant differences $(\mathrm{p}<0.005)$ in change of seedlings height between the 8th week and 4th from the seeds harvested in 2018 compared to 2017 (Table 3).

Results found that sinker seeds have high germination ability compared to floater seeds compared to floated cashew seeds (Tables 4-6). Seeds harvested in 2018 had many sinkers as compared to those harvested in 2016 and 2017 (Table 4).

Table 1. Shows germination capacity test results at TARI-Naliendele for Cashew seeds harvested in 2016, 2017 and 2018 season.

\begin{tabular}{ccccc}
\hline Y.H & N.S.S & \% G, 1 WASS & \% G, 2 WASS & \% G, 4 WASS \\
\hline 2018 & 100 & 0 & 72.6 & 99.6 \\
2017 & 100 & 0 & 2.7 & 52.4 \\
2016 & 100 & 0 & 0 & 0.0 \\
\hline
\end{tabular}

Y.H $=$ Year of harvest, N.S.S $=$ Number of seeds sown, $\% \mathrm{G}=$ Germination percent, 1 WASS $=$ one week after seed sowing, 2 WASS = two weeks after seed sowing, 4 WASS = four weeks after seed sowing. 
Table 2. Mean comparison for cashew seeds growth rate for 2 months after seeds sowing across years of harvest.

\begin{tabular}{ccc}
\hline & \multicolumn{2}{c}{ Year } \\
\cline { 2 - 3 } Parameter & 2018 & 2017 \\
\hline Diameter $(\mathrm{cm})$ & $21.8^{* *}$ & $15.2^{*}$ \\
Leaf Area Index & $0.24^{*}$ & $0.19^{\star}$ \\
Leaf Area $(\mathrm{sq} \mathrm{cm})$ & $67.9^{* *}$ & $41.0^{*}$ \\
Leaf Length $(\mathrm{cm})$ & $16.1^{* *}$ & $12.4^{*}$ \\
Leaf width $(\mathrm{cm})$ & $4.2^{* *}$ & $3.2^{\star}$ \\
Plant ground area $(\mathrm{sq} \mathrm{cm})$ & $383.9^{* *}$ & $189.1^{*}$ \\
\hline
\end{tabular}

F.pr $=0.05,{ }^{*}=$ There is no significant difference, ${ }^{* *}=$ There is significant difference.

Table 3. Mean comparisons of cashew seedlings height $(\mathrm{cm})$ and height change $4-8$ weeks after seeds sowing across years.

\begin{tabular}{cccc}
\hline Year & ${ }^{*}$ MHS4W & ${ }^{* *}$ MHS8W & ${ }^{* * *}$ MCHB4 \& 8W \\
\hline 2018 & 18.80 & 45.4 & 26.6 \\
2017 & 9.79 & 32.4 & 22.6 \\
LSD $_{0.05}$ & 3.525 & 4.99 & 5.75 \\
CV & 32.7 & 17.0 & 31.0 \\
P-value & $<0.001$ & $<0.001$ & $<0.001$ \\
SE \pm & 1.208 & 1.71 & 1.97 \\
\hline
\end{tabular}

${ }^{*} \mathrm{MHS} 4 \mathrm{~W}=$ Mean height $(\mathrm{cm})$ of seedlings 4 weeks after seeds sowing, ${ }^{*} \mathrm{MHS} 8 \mathrm{~W}=$ Mean height of seedlings 8 weeks after seeds sowing and ${ }^{* * *}$ MCHB4\&8W $=$ Mean change in height $(\mathrm{cm})$ between $4^{\text {th }}$ and $8^{\text {th }}$ week.

Table 4. Mean comparisons of number and percentage of cashew sinker and floater seeds.

\begin{tabular}{ccccc}
\hline Year & $\begin{array}{c}\text { Number of } \\
\text { sinker seeds }\end{array}$ & \% sinker seeds & $\begin{array}{c}\text { Number of } \\
\text { floater seeds }\end{array}$ & \% floater seeds \\
\hline 2018 & $80 \mathrm{~b}$ & $80 \mathrm{~b}$ & $20 \mathrm{a}$ & $20 \% \mathrm{a}$ \\
2017 & $56 \mathrm{ab}$ & $56 \mathrm{ab}$ & $44 \mathrm{ab}$ & $44 \% \mathrm{ab}$ \\
2016 & $39 \mathrm{a}$ & $39 \mathrm{a}$ & $61 \mathrm{~b}$ & $61 \% \mathrm{~b}$ \\
P-value & $\mathrm{p}<0.05$ & $\mathrm{p}<0.05$ & $\mathrm{p}<0.05$ & $\mathrm{p}<0.05$ \\
\hline
\end{tabular}

Note: different letters "a, b" across rows or columns describe significant difference between parameters (years or floaters and sinkers) and similar letter "a" or "b" indicates insignificant difference.

Table 5. Mean comparison of percentage germination between sinker and floater cashew seeds, two weeks after seed sowing across years.

\begin{tabular}{cccc}
\hline Year & N.S.S. & Sinkers & Floaters \\
\hline 2018 & 100 & 65 & 8 \\
2017 & 100 & 2.7 & 0 \\
2016 & 100 & 0 & 0 \\
\hline
\end{tabular}

Key. N.S.S = Number of seeds sown. 
Table 6. Mean comparison of percentage germination between sinker and floater cashew seeds, four weeks after sowing across years.

\begin{tabular}{cccc}
\hline Year & N.S.S. & Sinkers & Floaters \\
\hline 2018 & 100 & 90 & 9.6 \\
2017 & 100 & 50 & 2.4 \\
2016 & 100 & 0 & 0 \\
\hline
\end{tabular}

N.S.S $=$ Number of seeds sown

Seedlings from cashew seeds harvested in 2018 recorded significantly $(\mathrm{p}<$ 0.05 ) higher weight and many roots compared to seedlings from cashew seeds harvested in 2017 (Table 6 and Table 7; Figures 1-5). However, there was no germination for cashew seeds harvested in 2016.

\section{Discussion}

This study tested for germination capacity and assessed cashew seedling vigour in relation to seed storage duration. Our study revealed that cashew seeds sown in less than one year after the harvest had higher germination percent compared to cashew seeds sown more than one year after the harvest. Elongated storage duration decreases seed moisture which cause seed coat harder and becomes wrinkled hindering imbibition rate [20] [36].The longer the storage duration the lower the viability of seeds, hence poor germination [26] [37] [38].

We recorded higher leaf area index in seedlings from seeds harvested in 2018 compared to those harvested in 2017. Growth rate and yields is higher for plants with high area index [39] [40] [41] [42]. Leaf area index is associated with photosynthetic rate [39]. It plays a great role in remote sensing of cropping patterns, growth vigor of the plant and help to give prediction of crop productions [43] [44].

In case of floating test, results indicated that cashew seeds harvested in 2018 recorded more sinker seeds (80\%) compared to $39 \%$ and 56\% sinker seeds recorded from cashew seeds harvested in 2017 and 2016 respectively. The present study revealed high germination performance $(90 \%$ from seeds harvested in 2018 and 50\% from 2017 seeds) in sinker seeds compared to floaters (9.6 for 2018 and 2.4 for 2017 seeds). This implies that sinker seeds are more viable than floaters. In this study, it is clearly indicated that floating test as the viability determinant approach has succeeded by $90 \%$ based on germination for sinker seeds harvested in 2018 at the 4 th week after sowing. This implies that there is a chance to reduce plant population by $10 \%$ if all sinker cashew seeds are planted excluding floaters. Floaters germinated by $9.6 \%$ for seeds harvested in 2018 , implying that not all cashew seed floaters are not viable. It means that some viable seeds are reduced when discarding all floaters.

Based on germination capacity of $99.6 \%$ (sinkers $=90$ and floaters $9.6 \%$ ) recorded in cashew seeds harvested in 2018, this study confirmed that farmers should be supplied with cashew seeds of the current year regardless of floating test. 


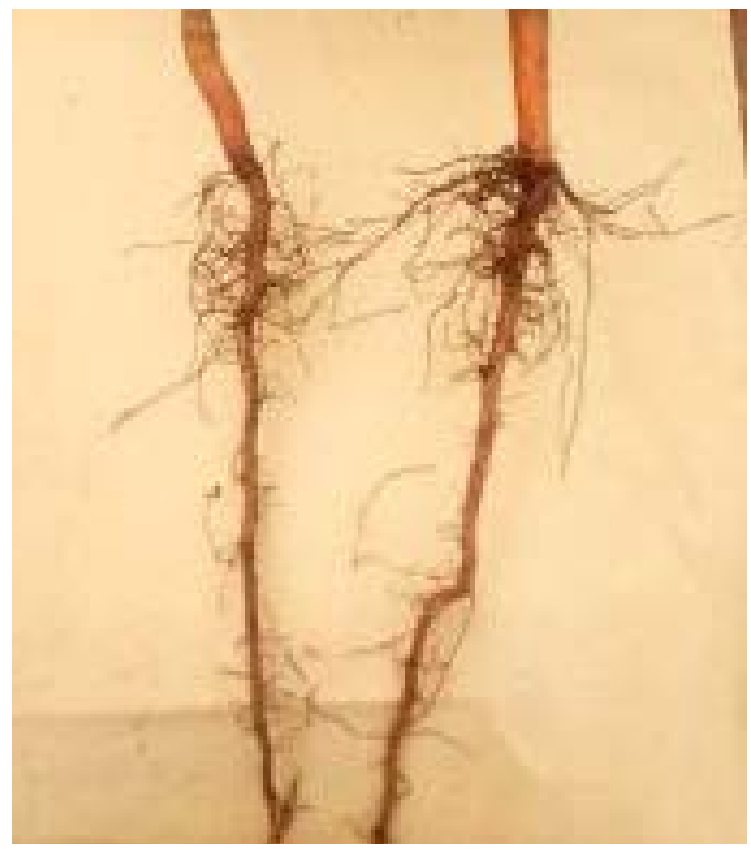

Figure 1. Roots of cashew seedling, 16 weeks after seed sowing for the seeds harvested in 2018.

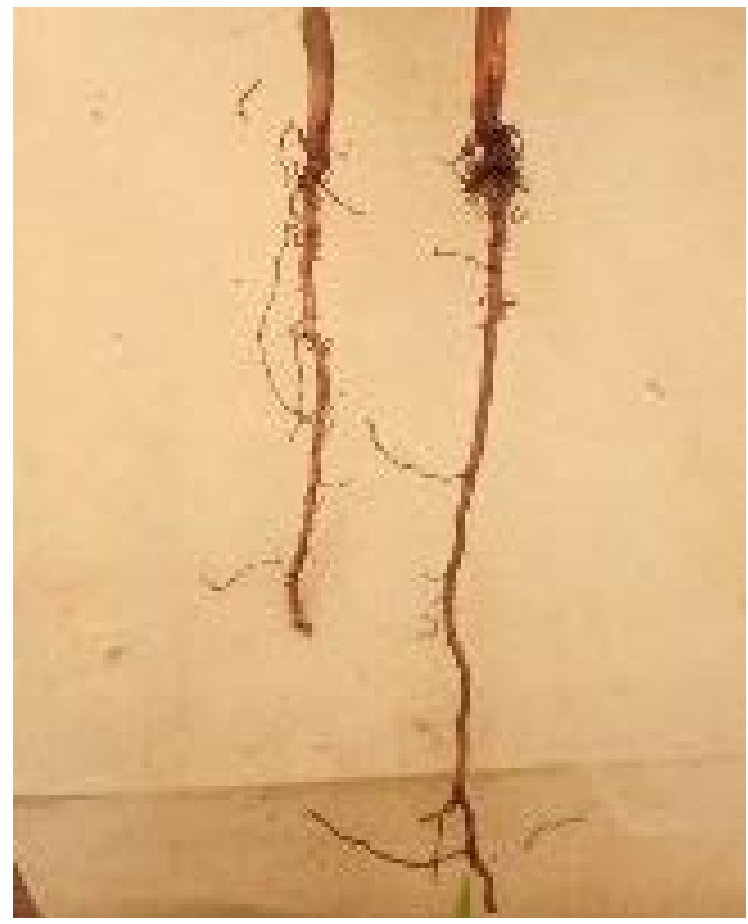

Figure 2. Roots of cashew seedling, 16 weeks after seed sowing for the seeds harvested in 2017.

quality is determined by the seed coats characteristics and floatability in water [36]. This justifies the necessity of floating tests and thus the floaters were weaker than the sinkers as per results. Since seeds harvested in 2016 and 2017 had many floaters as these were weak compared to those harvested in 2018. However, 


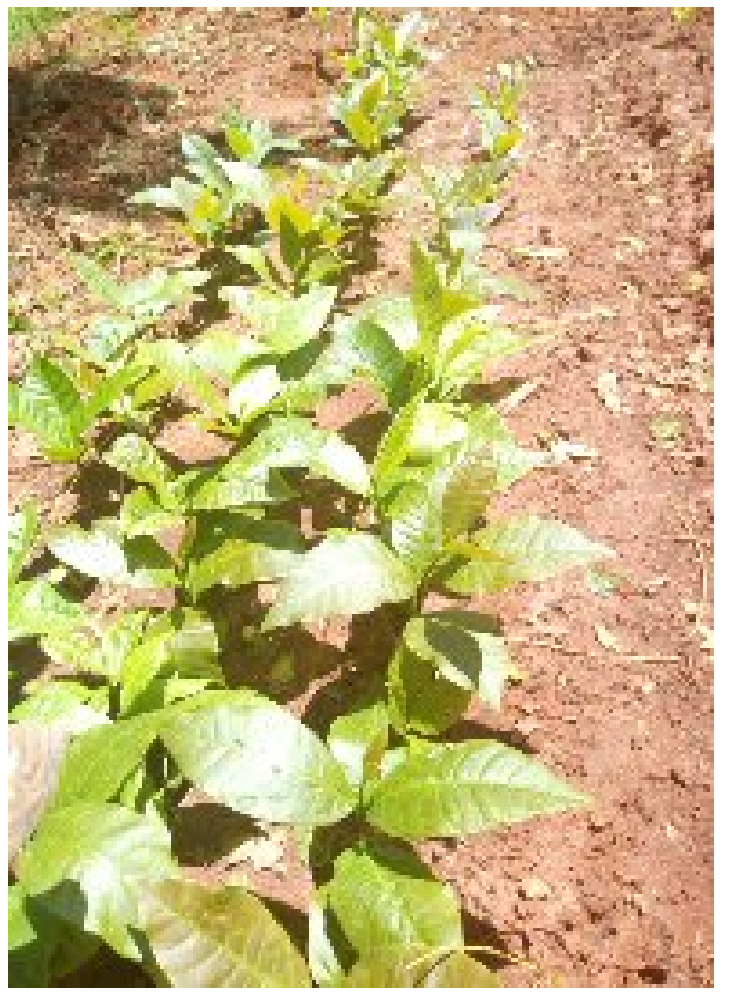

Figure 3. Cashew seedlings, two weeks after sowing, the seeds harvested in 2018.

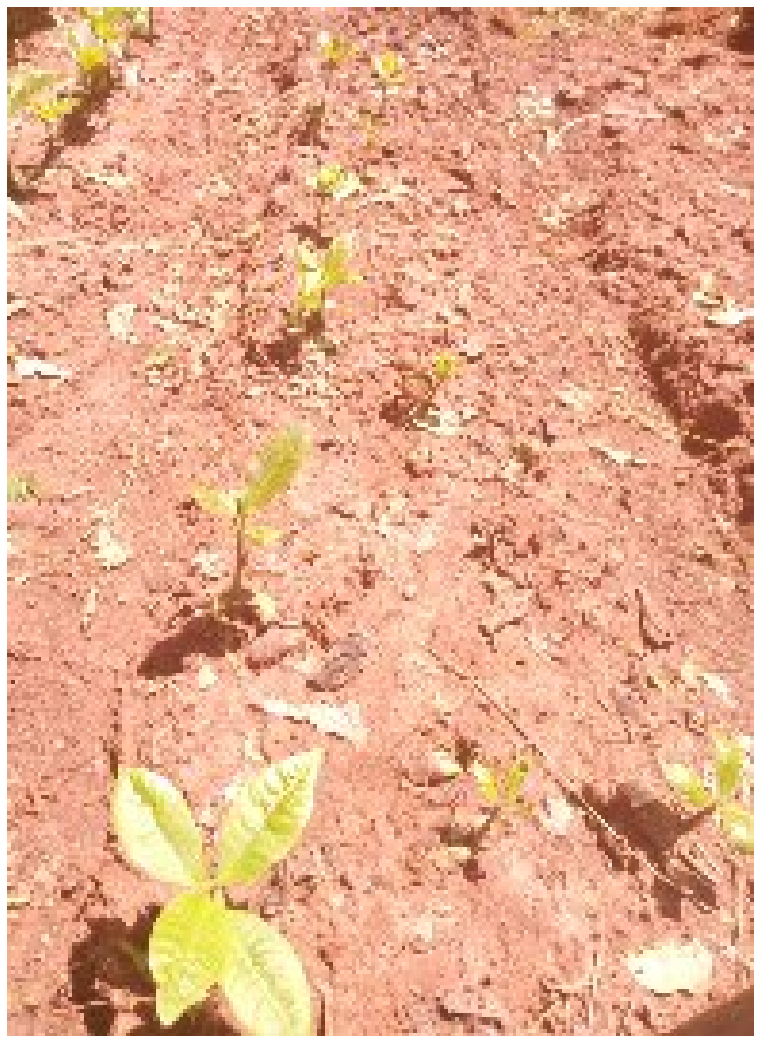

Figure 4. Cashew seedlings, two weeks after sowing, the seeds harvested in 2017. 


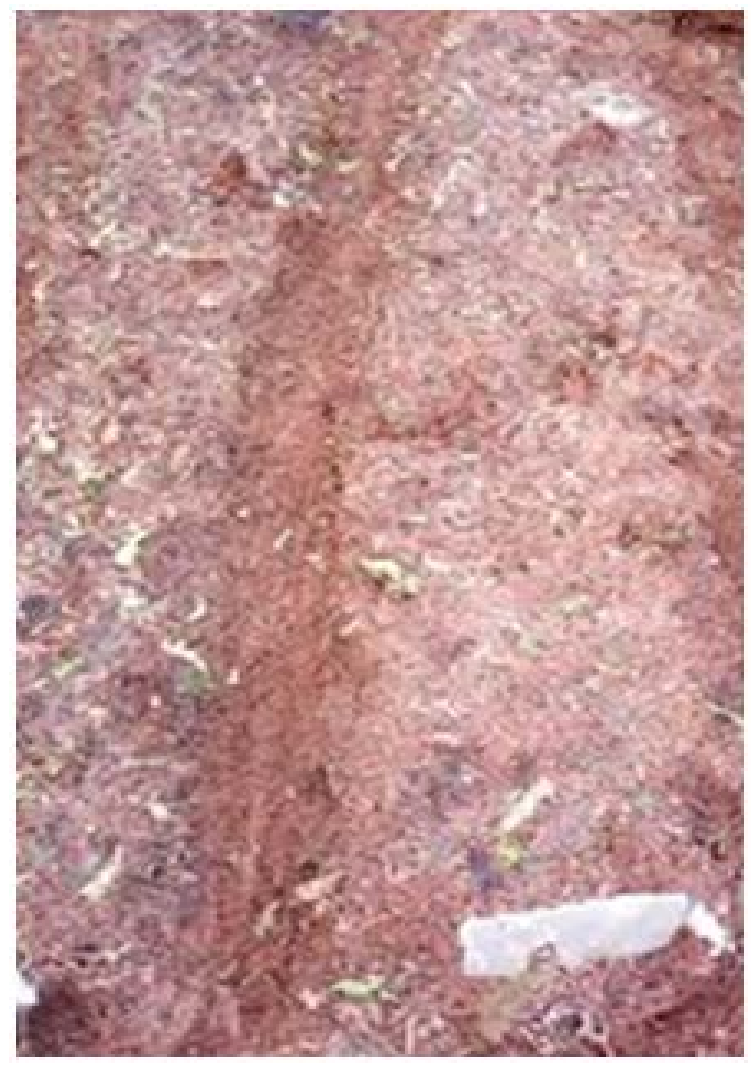

Figure 5. The Cashew seedbed with no seedlings germinated, two weeks after sowing, seeds harvested in 2016.

Table 7. Mean comparison of cashew seedlings fresh and dry weight (g) and number of roots 16 weeks after seed sowing across years.

\begin{tabular}{|c|c|c|c|}
\hline Year & ${ }^{* * *}$ FW16wk & ${ }^{* * *} \mathrm{DW} 16 \mathrm{wk}$ & ${ }^{* * *} \mathrm{NR} 16 \mathrm{wk}$ \\
\hline 2018 & 15.6 & 3.8 & 111 \\
\hline 2017 & 10.4 & 2.7 & 63 \\
\hline LSD0.05 & 3.06 & 1.00 & 34.62 \\
\hline $\mathrm{CV}$ & 31.3 & 40.5 & 52.7 \\
\hline $\mathrm{P}$-value & 0.002 & 0.032 & 0.008 \\
\hline $\mathrm{SE} \pm$ & 1.05 & 0.34 & 11.86 \\
\hline
\end{tabular}

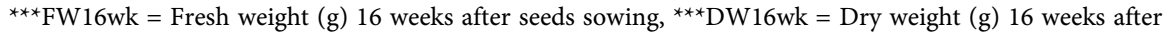
seeds sowing and ${ }^{* *}$ NR $16 \mathrm{wk}=$ Number of cashew seedlings roots 16 weeks after seeds sowing.

Seedlings from seeds harvested in 2018 performed better with many roots and higher fresh and dry weight compared to seedlings from seeds harvested in 2017. Increased nutritional content of cotyledons improves embryo functioning for seed germination and good performance of seedlings [13] [14] [15]. Plant roots pattern modified with many and healthier root hairs and tap roots indicate good performance of seedlings [46]. Health roots ensure plant cells turgidity and efficient uptake of plant nutrients. 


\section{Conclusion and Recommendation}

The present study found a $99.6 \%$ germination capacity for cashew seeds sown in less than one year after harvesting. However, no germination was recorded for cashew seeds sown after two years from harvesting time. This implies that cashew seed viability decreases with the increase in storage duration. The study also revealed that sinker seeds are more viable compared to floater seeds. However, neither all sinker seeds are viable nor all floater seeds are not viable. Therefore, cashew farmers should be supplied with cashew seeds harvested from the current season. Further study is required to improve the floating test method that can reduce viable seeds from floaters and inviable seeds from sinkers.

\section{Acknowledgements}

All thanks are to be sent to the Government of the United Republic of Tanzania through Tanzania Agriculture Research Institute (TARI) at the center of Naliendele, Mtwara for financial and material support on the research work. TARI-Naliendele is greatly acknowledged for approving this study and its advisory guiding on this research work. We appreciate Hamida Mussa Bwaize and Mohamedi Hassani Kindete for their contribution to maintaining the trial and supervising the experimental progress as well as their lead on data collection.

\section{Conflicts of Interest}

The authors declare no conflicts of interest regarding the publication of this paper.

\section{References}

[1] Catarino, L., Menezes, Y. and Sardinha, R. (2015) Cashew Cultivation in Guinea-Bissau-Risks and Challenges of the Success of a Cash Crop. Scientia Agricola, 72, 459-467. https://doi.org/10.1590/0103-9016-2014-0369

[2] Adeigbe, O.O., Muyiwa, A.A., Adewale, B.D. and Olasupo, F.O. (2015) A Review on Cashew Research and Production in Nigeria in the Last Four Decades. Scientific Research Essays, 10, 196-209. https://doi.org/10.5897/SRE2014.5953

[3] Nhantumbo, A. (2017) Determinants of Adoption of Technologies for Cashew Production in Nampula, Mozambique. Journal of Experimental Agriculture International, 17, 1-11.

[4] Masenya, C., et al. (2018) Bank of Tanzania.

[5] Azam-Ali, S. and Judge, E. (2001) Small-Scale Cashew Nut Processing. J Coventry, ITDG Schumacher Centre for Technology Development Bourton, Dunsmore.

[6] Mitra, A., Pramanick, P. and a Parkhi, U. (2015) Leaf Composition of Cashew (Anacardium occidentale. L): A Case Study from the Jajpur District, Odisha. Journal of Chemical, Biological Physical Sciences, 5, 2634.

[7] Dasgupta, P., et al. (2012) Rural Areas.

[8] Antwi-Agyei, P., Fraser, E.D.G., Dougill, A.J., Stringer, L.C. and Simelton, E. (2012) Mapping the Vulnerability of Crop Production to Drought in Ghana Using Rainfall, Yield and Socioeconomic Data. Applied Geography, 32, 324-334. 
https://doi.org/10.1016/j.apgeog.2011.06.010

[9] Bhavya, V.P., Anil Kumar, S., Ashok Alur, S.K.K., Shivakumar, K.M. and Shivanna, M. (2018) Effect of Different Cropping System on Important Soil Enzyme Activity, Orga nic Carbon and Microbial Activity with Different Depth. International Journal of Current Microbiology and Applied Sciences, 7, 315-322.

https://doi.org/10.20546/ijcmas.2018.701.034

[10] Pye, S., Watkiss, P. and Savage, M. (2010) Opportunities for Low Carbon Investment in Tanzania-An Assessment of Future Emissions Growth and Low Carbon Reduction Potential. Stockholm Environment Institute, UK.

[11] Aravindakshan, K., et al. (1986) Studies on Certain Physico-Chemical Attributes of Apple and Nuts of Selected Cashew Types. Cashew Causerie, 8, 5-8.

[12] Naka, T. and Martin, D.K. (2016) Assessment of Some Biochemical Parameters of Apple Juices from Two Cashew Varieties as Affected by Three Regions of co'te $\mathrm{d}$ Ivoire. Journal of Advances in Agriculture, 5, 621-633.

[13] Makule, E.E, Masawe, P. and Kassim, N. (2017) Physio-Chemical Properties of Five Cashew Apple (Anacardium occidentale L.) Varieties Grown in Different Regions of Tanzania. International Journal of Biosciences, 11, 386-395.

[14] Masawe, P.A.L. and Kapinga, F.A. (2017) The First Dwarf Cashew Varieties in Tanzania. Dar es Salaam: CRP ARI, Naliendele.

[15] Sabaté, J. (2003) Nut Consumption and Body Weight. The American journal of Clinical Nutrition, 78, 647-650. https://doi.org/10.1093/ajcn/78.3.647S

[16] Ngwegwe, S.S. (2019) Determinants of Tanzanian Business Community Engagement in Export Trade-In Dar Es Salaam: A Case of Agricultural Products. College of Business Education, Tanzania.

[17] Kidunda, B.R., Kasuga, L.J., Magani, S.F. and Mwakanyamale, D.F. (2013) Adoption of Cashew Production Technologies by Farmers in the South Eastern Tanzania. Proceedings of 2013 International Conference on Food and Agricultural Sciences, Melakaelaka, 5 October 2013, 94-99.

[18] Adebisi, M.A., Kehinde, T.O., Abdul-Rafiu, A.M., et al. (2015) Influence of Nut Size, Hydro Priming Duration and Storage Period on Seedling Emergence and Early Seedling Vigour Characters in Cashew (Anacardium occidentale L.). Pertanika Journal of Tropical Agricultural Science, 38, 465-480.

[19] Kehinde, T., Adebisi, M.A., Alegiledoye, A.O., Ajani, O.O. and Shofuyi, K.A. (2015) Evaluation of Seed Nut Size as Index of Selection for Superior Seed Quality Attributes in Two Biotypes of Cashew (Anacardium occidentale). Plant Breeding, 72, 69-81. https://doi.org/10.1515/plass-2015-0032

[20] Pradhan, B.K. and Badola, H.K. (2012) Effect of Storage Conditions and Storage Periods on Seed Germination in Eleven Populations of Swertia chirayita: A Critically Endangered Medicinal Herb in Himalaya. The Scientific World Journal, 2012, Article ID: 128105. https://doi.org/10.1100/2012/128105

[21] Freeland, P. (1976) Tests for the Viability of Seeds. Journal of Biological Education, 10, 57-64. https://doi.org/10.1080/00219266.1976.9654060

[22] Agrios, G.N. (2005) Plant Pathology. Academic Press, Amsterdam.

[23] Dahamarudin, L. and Rivaie, A. (2013) Germination Capacity, Growth and Yield of Three Upland Rice Varieties Increased Following Seed Invigoration Treatments. International Research Journal of Agricultural Science Soil Science, 3, 43-50.

[24] Akos, I., Tagwai, M. and Dabo, J. (2017) Effect of Interaction between Seed Size and Sowing Depth of Cashew Anacardium occidentale (L) on Seedlings Emergence and 
Height Under Treatment with Organic and Inorganic Fertilizer in Gidan-Waya, Southern Guinea Savanna, Nigeria. Science World Journal, 12, 28-35.

[25] Bezerra, M.A., de Lacerda, C.F., Filho, E.G., et al. (2007) Physiology of Cashew Plants Grown under Adverse Conditions. Brazilian Journal of Plant Physiology, 19, 449-461. https://doi.org/10.1590/S1677-04202007000400012

[26] Oyewole, C. and Koffa, K. (2010) Effect of Storage, Size of Nut and Soaking Length on Sprout Emergence in Cashew. Thai Journal of Agricultural Science, 43, 39-45.

[27] Adesina, J.M., Adedire, O. and Adeyemi, J.A. (2017) Potential of Four Tropical Plant Powders as Grain Protectants against Callosobruchus maculatus (Coleoptera: chrysomelidae). Progress in Biological Sciences, 7, 119-126.

[28] Van Waes, J. and Debergh, P. (1986) Adaptation of the Tetrazolium Method for Testing the Seed Viability, and Scanning Electron Microscopy Study of Some Western European Orchids. Physiologia Plantarum, 66, 435-442. https://doi.org/10.1111/j.1399-3054.1986.tb05947.x

[29] Zanjan, M.G. and Asli, D.E. (2012) A Study of Seed Germination and Early Seedling Growth of Wheat Genotypes Affected by Different Seed Pyridoxine-Priming Duration. Annals of Biological Research, 3, 5687-5691.

[30] Yuan, X. and Wen, B. (2018) Seed Germination Response to High Temperature and Water Stress in Three Invasive Asteraceae Weeds from Xishuangbanna, SW China. PloS ONE, 13, e0191710. https://doi.org/10.1371/journal.pone.0191710

[31] Mao, P., Guo, L., Gao, Y.X., et al. (2019) Effects of Seed Size and Sand Burial on Germination and Early Growth of Seedlings for Coastal Pinus thunbergii Parl. in the Northern Shandong Peninsula, China. Forests, 10, 281.

https://doi.org/10.3390/f10030281

[32] Reed, S. (2005) Effect of Storage Temperature and Seed Moisture on Germination of Stored Flowering Dogwood Seed. Journal of Environmental Horticulture, 23, 29-32. https://doi.org/10.24266/0738-2898-23.1.29

[33] Conacher, C., Poiner, I.R., Bultler, J., et al. (1994) Germination, Storage and Viability Testing of Seeds of Zostera capricorni Aschers. from a Tropical Bay in Australia. Aquatic Botany, 49, 47-58. https://doi.org/10.1016/0304-3770(94)90005-1

[34] Breda, N.J. (2003) Ground-Based Measurements of Leaf Area Index: A Review of Methods, Instruments and Current Controversies. Journal of Experimental Botany, 54, 2403-2417. https://doi.org/10.1093/jxb/erg263

[35] Souza, F.H. and Marcos-Filho, J. (2001) The Seed Coat as a Modulator of Seed-Environment Relationships in Fabaceae. Brazilian Journal of Botany, 24, 365-375. https://doi.org/10.1590/S0100-84042001000400002

[36] Guberac, V., Lalic, A., Maric, S., et al. (2003) Hermetically Sealed Storage of Cereal Seeds and Its Influence on Vigour and Germination. Journal of Agronomy, 189, 54-56.

[37] Aliyu, O.M. and Akintaro, G.O. (2007) Studies on the Effect of Storage Period and Nut Size on the Seedling Vigour of Cashew. American-Eurasian Journal of Scientific Research, 2, 68-74.

[38] Simpson, G. (1968) Association between Grain Yield Per Plant and Photosynthetic Area above the Flag-Leaf Node in Wheat. Canadian Journal of Plant Science, 48, 253-260. https://doi.org/10.4141/cjps68-046

[39] Ewert, F. (2004) Modelling Plant Responses to Elevated $\mathrm{CO}_{2}$ : How Important Is Leaf Area Index? Annals of Botany, 93, 619-627.

https://doi.org/10.1093/aob/mch101 
[40] Luo, T., Pan, Y.D., Ouyang, H., et al. (2004) Leaf Area Index and Net Primary Productivity along Subtropical to Alpine Gradients in the Tibetan Plateau. Global Ecology, 13, 345-358.

[41] Weis, I.M. (1982) The Effects of Propagule Size on Germination and Seedling Growth in Mirabilis hirsuta. Canadian Journal of Botany, 60, 1868-1874. https://doi.org/10.1139/b82-233

[42] McDowell, N.G., Adams, H.D., Baily, J.D., et al. (2007) The Role of Stand Density on Growth Efficiency, Leaf Area Index, and Resin Flow in Southwestern Ponderosa Pine Forests. Canadian Journal of Forest Research, 37, 343-355. https://doi.org/10.1139/X06-233

[43] Asrar, G., Fuchs, M., Haltfield, J.L., et al. (1984) Estimating Absorbed Photosynthetic Radiation and Leaf Area Index from Spectral Reflectance in Wheat. Agronomy journal, 76, 300-306.

https://doi.org/10.2134/agronj1984.00021962007600020029x

[44] Reiser, L. and Fischer, R.L. (1993) The Ovule and the Embryo Sac. The Plant Cell, 5, 1291. https://doi.org/10.2307/3869782

[45] Zhu, J., Zhang, C. and Lynch, J.P. (2010) The Utility of Phenotypic Plasticity of Root Hair Length for Phosphorus Acquisition. Functional Plant Biology, 37, 313-322. https://doi.org/10.1071/FP09197

[46] Shabala, S.N. and Lew, R.R. (2002) Turgor Regulation in Osmotically Stressed Arabidopsis Epidermal Root Cells. Direct Support for the Role of Inorganic Ion Uptake as Revealed by Concurrent Flux and Cell Turgor Measurements. Journal of Plant Physiology, 129, 290-299. https://doi.org/10.1104/pp.020005 